\title{
Soil Structure Evaluation Across Geologic Transition Zones Using 2D Electrical Resistivity Imaging Technique
}

\author{
Geraldine C. Anukwu ${ }^{1,2, *}$, A. F. Adebara ${ }^{1}$, T.K. Abodunrin ${ }^{3}$, A. P Iwakun ${ }^{3}$ \\ ${ }^{1}$ Department of Geosciences, University of Lagos, Akoka, Lagos, Nigeria. \\ ${ }^{2}$ Geophysics Program, School of Physics, Universiti Sains Malaysia, Pulau Pinang \\ ${ }^{3}$ Department of Physics, Olabisi Onabanjo Univsersity, Ago-Iwoye, Nigeria.
}

* Corresponding author : geraldineijeoma@gmail.com

Received: 11 April, 2017. Revised : 2 May 2017, Accepted: 31 May, 2017, Published: 1 June 2017

DOI: 10.24273/jgeet.2017.2.2.195

\begin{abstract}
This study utilizes the electrical resistivity values obtained using 2-D Electrical resistivity imaging (ERI) technique to evaluate the subsurface lithology across different geological units. The primary objective was to determine the effect of subsurface lithology on the integrity of a road pavement, which had developed cracks and potholes at various locations. The dipole-dipole configuration was utilized and a total of nine traverses were established in the study area, whose geology cuts across both the basement and sedimentary complexes. The inverted resistivity section obtained showed significant variation in resistivity along established traverses and also across the different rock units, with the resistivity value ranging from about $4 \mathrm{ohm}-\mathrm{m}$ to greater than $7000 \mathrm{ohm}-\mathrm{m}$. The lithology as interpreted from the resistivity section revealed the presence topsoil, clay, sandy clay, sand, sand stones/basement rocks, with varying vertical and horizontal arrangements to a depth of $40 \mathrm{~m}$. Results suggest that the geologic sequence and structure might have contributed to the observed pavement failure. The capability of the 2D ERI as an imaging tool is observed, especially across the transition zones as depicted in this study. The study further stressed the ability of this technique if properly designed and implemented, to be capable of providing a w ealth of information that could complement other traditional geotechnical and geologic techniques.
\end{abstract}

Keywords: Electrical Resistivity Imaging, Transition zone, Ago-Iwoye, Nigeria

\section{Introduction}

\subsection{Sub Introduction}

As a means of ensuring the continuous integrity of engineering structures long after their completion, it is important that the subsurface on which such structures are built upon is properly considered. The presence of potholes, cracks, bulges/and or depressions are common occurrence along roads in southern part of Nigeria. Various factors have being attributed to the probable cause of failure which include poor quality construction, improper design and specification, poor drainage and improper usage, poor soil properties (Onuoha et al 2014). Most times, adequate attention is not given to the fact that the subsurface that provides the needed support for the road can be a major cause of failure. Research have however shown that there is need to put into consideration the geology and geomorphology of the underlying earth materials as they can greatly affect the integrity of any road (Ajayi, 1987; Olorunfemi and Meshida, 1987; Momoh et al 2008 and Adiat et al 2009; Ayolabi and Adegbola, 2013, Igwe, 2015).

To obtain a proper understanding of the characteristics of the underlying earth materials, various approaches can be adopted; one of such is the geophysical techniques. The advantages offered by the geophysical techniques is that they are generally non-invasive, non-destructive and of better spatial coverage (Sobreira et al 2010, Emujakporue, 2012). Some of the geophysical techniques that can be employed to achieve the desired information for investigating subsurface conditions are: seismic refraction, seismic reflection, MASW, ReMi, Ground Penetrating Radar; Electromagnetic Method; Electrical Resistivity, Magnetic, (Wightman et al 2004; Anderson, 2008).

Electrical resistivity techniques have been successfully applied in characterizing the subsurface for many years with applications ranging from hydrogeological, archeological, environmental and engineering studies (Adepelumi and Olorunfemi, 2000; Rizzo et al 2005; Alaia et al 2007; Ariyo and Adeyemi, 2012).The electrical method makes use of the response of the subsurface to current introduced into the ground via electrodes. The measurements obtained can be used to obtain apparent resistivity of the subsurface materials, from which the true resistivity can be implied. The resistivity distribution observed thus forms the basis for identifying the earth materials present in such geologic environments. Resistivity 
methods applied in road investigation has been reported by quite a number of researchers (Momoh et al 2008; Oladapo et al 2008; Adiat et al 2009; Emujakporue, 2012). These authors in their works utilized 1D resistivity measurements (Vertical Electrical Sounding and/or profiling) to characterize the subsurface as well as identify faults and other geologic units that were detrimental to the integrity of the road.

Advances in instrumentation and computer algorithm has led to the development of 2D, 3D electrical imaging technique using multi-electrode resistivity systems which is more cost-effective and capable of providing a better representation of the subsurface (Loke, 2004; Kumar, 2012; M etwaly and AlFouzan, 2013). In the 2-D electrical imaging method, resistivity changes in both vertical and horizontal direction along the survey line are accounted for. Here, the implementation of the technique involves the use of a large number of electrodes $(>25)$. These el ectrodes are connected by means of a multi-core cable, which is in turn connected a switching unit (electrode selector) and to the resistivity meter. The electrode selector is capable of automatically selecting four electrodes as needed for each measurement.

Thestudy therefore aims to employ 2-D ERI with its inherent advantages when compared to 1-D resistivity measurements to determine the effect of subsurface lithology on the integrity of the pavement along Ago-Iwoye to Ishara road, which had developed cracks and potholes at various locations. As the study spans through a geological transition zones, the results presented can also serve as a guide to aid the proper deployment of techniques and solutions that can guide against the occurrence of such failures along the studied road and places with similar geological settings.

\section{Geological Setting}

The study area is located between longitude $\mathrm{N}$ 06057.0711 - N 07000.3811 and latitude E 0030 54.7721- E 003042.2711 respectively with an average elevation of 71 meters. The road investigated in this study is the asphalt pavement roadway from Ago-Iwoye to Ishara passing along Okegbe and Imagbon villages, all in Ogun State (Fig.1.).

The road serves as a link between the University (Olabisi Onabanjo University) town of Ago-Iwoye and another town Ishara which then connects to other major cities in the southwest these includes Abeokuta, Lagos and Ibadan. As at the time this study was conducted, the road had undergone major failures on some portion, which necessitated this study to determine the effect of the subsurface conditions on the failure of the road.

Rocks in the study area falls in both the Basement and Sedimentary complexes of sourth western Nigeria, with the Northwestern part (AgoI woye axis) comprising of basement complex rocks and the sourthern part (Ishara axis) having sedimentary rocks. Somewhere in between lies the contact between both geological zones (Fig. 1.). Extensive studies have been done by several authors on the geology of the southwestern Nigeria, describing both rock types. The basement complex of Nigeria show four distinct lithologies: etrologicgneiss complex, metasedimentary and metavolcanic rocks (The Schist Belts), the PanAfrican granitoids (The Older Granites), and the undeformed Acid and Basic dykes of the study area belongs to the Schist (Rahaman, 1989).

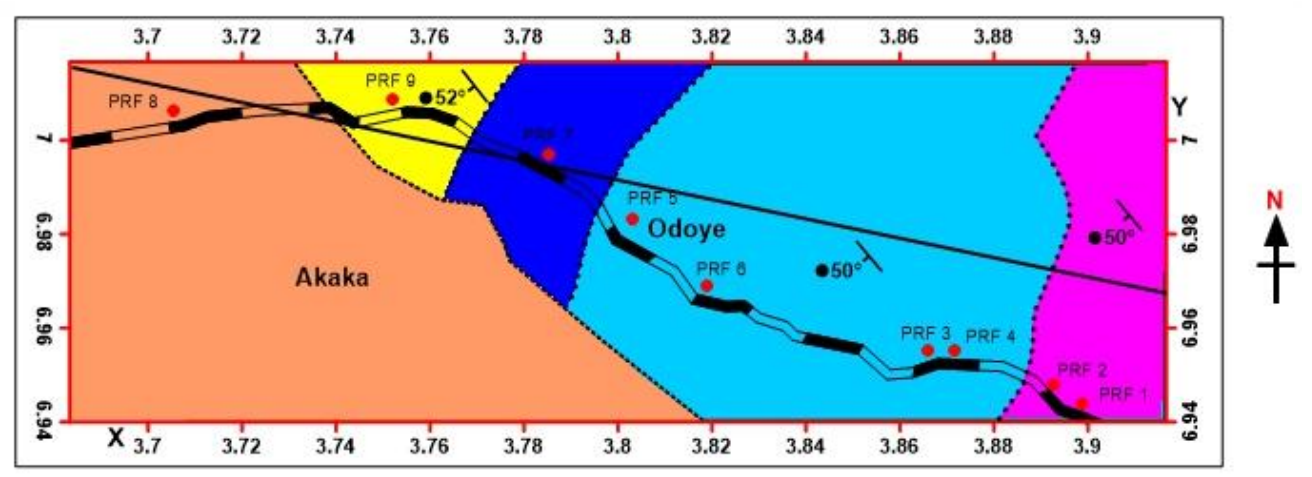

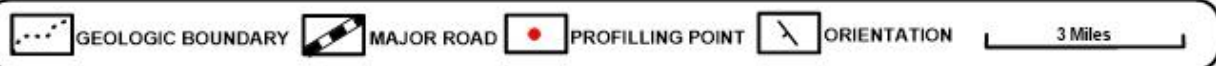

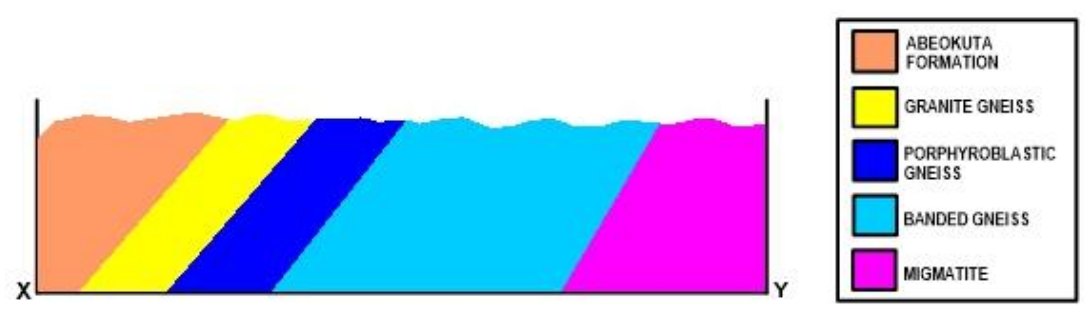

Fig. 1. Map of the study area showing traverses and geologic boundary 
The basement rock type of the study area falls under the Schist belt lithology and is made up of low grade, metasediment-dominated belts occupying $\mathrm{N}-\mathrm{S}$ trending synformal troughs. They are infolded into the older Migmatite-Gneiss Complex. On the other hand, the sedimentary part belongs to the Abeokuta group, of which the following formations have been esablished: Ise, Araromi and Afowo (Omatsola and Adegoke, 1981). Lithologies identified in these formations include: sandstones, grits, siltstones, limestones, shales and sands.

\section{Materials And Method}

The 2D electrical imaging involved the establishment of nine traverses in the study area utilizing the Dipole-Dipole Configuration (Fig. 1.). The nine traverses were along the North - east direction of the expressway starting from the AgoIwoye axis of the road. Resistivity measurements were obtained using the SuperSting R8/IP 8 resistivity meter system, developed by the Advanced Geosciences Inc., (AGI). A total of 84 electrodes were deployed along a linear arraywith an electrode spacing of $2 \mathrm{~m}$.

The acquired data can generally be displayed as pseudosections, which provide an approximate estimate of the subsurface resistivity variation. In order to obtain a true picture of the subsurface, an inversion of the data needs to be done. For our study, the RES2DINV software was used to analyze the data i.e. plotting the 2D pseudosection and inversion. Loke (2004) describes the algorithm used by the program for inversion, which is based on a smoothness constrained least squares approach.

As a means of comparing and validating results, one of the traverses was done on the stable portion of the road which had no visible cracks and potholes as at the time of this study. The resistivity signature from this portion was compared to the others in order to confirm the resistivity signatures obtained from the subsurface.

\section{Results And Discussion}

The result of the inverted resistivity sections for all traverses and their corresponding interpretation are presented in table 1 . The lithological sequence inferred from the resistivity values for all the traverses shows variation in the depth to bedrock and structure which is dependent on the rock type that characterizes the location (Table 1). The lithology sequence ranges includes topsoil, clay, clayey sand/sand (saturated unit), fresh bedrock. The thickness of the layers varies al ong the traverse, however, the maximum depth of investigation obtained is $40 \mathrm{~m}$.

As the traverses cuts across different geological boundaries, it is expected that the resistivity signature will vary as the resistivity value is a function of the composition amongst many other factors. The range of values obtained from the measurements, as we traverse north-eastwards toward the sedimentary boundary is presented in table 2. It is observed that the val with , The resistivity value Only one of the traverses (Traverse 8) falls on the sedimentary complex, as observed on the geological map (Fig. 1.). The basement complex rock type ranges from migmatite, banded gneiss, porphyroblastic gneiss and granite gneiss. The highest resistivity values obtained for the basement complex rocks corresponds to that reported by Olayinka and Sogbetun, 2002. The relatively low resistivity ranges obtained for traverses 2, 4, 3 and 9 can be as a result of the structural features observed along the profile ranging from possible faulting and depressions. The complex interplay of lithology, even within similar geological formation is as such a paramount reason that should necessitate adequate site investigation for any infrastructure development.

Critical observation of the resistivity sections for possible causes of pavement failure is presented as follows. Fig. 2. shows the resistivity sections of traverses 1 and 2 . These traverses both fall on the basement complex, with varying degree of pavement failure. Field observation revealed the presence of potholes on the road at distances $112 \mathrm{~m}$ to $168 \mathrm{~m}$ along traverse 1 , while the frequency of the potholes where higher on traverse 3 . The second lithologic layer exhibits a relatively low resistivity of about 64.5 ohm-m to 9.58 ohm-m for both traverses. This low resistivity layer we have inferred as clay (Ariyo and Adeyemi, 2012). Igwe (2015) reported that the presence of large expanse of clay as one of the probable causes of pavement failure, as it might lead to differential settlement. The presence of potholes at the observed positions on traverse 1 coincides with the observed low resistivity at these positions. This low resistivity layer stretches almost all through traverse 2, a possible cause of the higher frequency of potholes along this traverse. The basement geometry for both of the traverses show marked variations. The maximum obtained resistivity for traverse 2 is far lower than that of traverse one (table 2). The resistivity of the fresh bedrock as interpreted is greater than $1000 \mathrm{ohm}-\mathrm{m}$. The resistivity value of more than 1000 ohm- $m$ was used as the cut off for the basement for the traverses that fall on the basement complex as has been reported in other research work in the study area (Omosanya et al 2012; Ariyo and Adeyemi, 2012). Unlike in traverse 1 , in which the basement is seen to run all through the traverse, a bedrock depression is observed. Ariyo and Adeyemi (2012) also reported that such bedrock depressions characterize the study area, which can also be seen in on the resistivity section. Also, the presence of a high resistivity material line positions 36 - 72m and $94-100 \mathrm{~m}$; at depths of 10 $-20 \mathrm{~m}$ and $5-10 \mathrm{~m}$ respectively. This high resistive material we have identified as possible boulders. The resistivity values surrounding these features show values that suggests possibly saturated layers (269 - $698 \mathrm{ohm}-\mathrm{m})$. The closeness of such saturated layer to the surface can lead to failure as the presence of moisture at the base/sub-base can decrease the strength of the road (Igwe, 2015). 
Table 1. Geoelectric layer for traverse 1

\begin{tabular}{|c|c|c|c|c|}
\hline Traverse & Layer & Resistivity $(\Omega \mathrm{m})$ & Depth & Inferred Lithology \\
\hline \multirow{4}{*}{1} & 1 & $64.5-167$ & $0-2$ & Topsoil \\
\hline & 2 & $<64.5$ & $2-10$ & Clay \\
\hline & 3 & $167-699$ & $5-12$ & Sandy Clay /Sand \\
\hline & 4 & $>1125$ & $>12$ & Fresh Basement \\
\hline \multirow{4}{*}{2} & 1 & $<1125$ & $0-2$ & Topsoil \\
\hline & 2 & $<64.5$ & $2-10$ & Clay \\
\hline & 3 & $167-434$ & $10-40$ & Sandy Clay/Sand \\
\hline & 4 & $>1125$ & $>12$ & Fresh Basement \\
\hline \multirow{4}{*}{3} & 1 & $64.5-1125$ & $0-5$ & Topsoil \\
\hline & 2 & $9.58-104$ & $2-15$ & Clay \\
\hline & 3 & $167-434$ & $10-25$ & Sandy Clay /Sand \\
\hline & 4 & $>1125$ & $12-40$ & Fresh Basement \\
\hline \multirow{3}{*}{4} & 1 & $167-1812$ & $1-10$ & Topsoil \\
\hline & 2 & $104-698$ & $10-32$ & Sandy Clay/Sand \\
\hline & 3 & $>1125$ & $32-40$ & Fresh Basement \\
\hline \multirow{3}{*}{5} & 1 & $>167$ & $0-5$ & Topsoil \\
\hline & 2 & $9.58-698$ & $5-12$ & Clay/Clayey Sand/Sand \\
\hline & 3 & $>1125$ & $5-40$ & Bedrock (Sandstones) \\
\hline \multirow{4}{*}{6} & 1 & $9.58-1125$ & $0-5$ & Topsoil \\
\hline & 2 & $9.58-103$ & $3-25$ & Clay \\
\hline & 3 & $167-698$ & $12-35$ & Sandy Clay/Sand \\
\hline & 4 & $>1125$ & $7-40$ & Bedrock (Sandstones) \\
\hline \multirow{4}{*}{7} & 1 & $64.5-1125$ & $0-1$ & Topsoil \\
\hline & 2 & $9.58-103$ & $1-10$ & Clay \\
\hline & 3 & $167-698$ & $5-10$ & Sandy Clay/Sand \\
\hline & 4 & $>1125$ & $10-40$ & Bedrock (Sandstones) \\
\hline \multirow{5}{*}{8} & 1 & $103.8-434$ & $0-5$ & Topsoil \\
\hline & 2 & $167-1182$ & $5-10$ & Sandy Clay/Sand \\
\hline & 3 & $<104$ & $8-25$ & Clay \\
\hline & 4 & $167-698$ & $25-35$ & Sandy Clay/Sand \\
\hline & 5 & $>1125$ & $31-40$ & Bedrock (Sandstones) \\
\hline \multirow{3}{*}{9} & 1 & $269-1125$ & $0-2$ & Topsoil \\
\hline & 2 & $<104$ & $2-35$ & Clay \\
\hline & 3 & $269-434$ & $10-40$ & Sand \\
\hline
\end{tabular}

Table 2

Apparent resistivity range across the study area

\begin{tabular}{lcccc}
\hline Geological Setting & Traverse $\begin{array}{c}\text { Lowest Apparent Resistivity } \\
(\mathrm{ohm}-\mathrm{m})\end{array}$ & $\begin{array}{c}\text { Highest Apparent } \\
\text { Resistivity (ohm-m) }\end{array}$ & Rock Type \\
\hline \multirow{3}{*}{ Basement Complex } & 1 & 7.55 & 24920 & Migmatite \\
\cline { 2 - 5 } & 2 & 3.9 & 2917.8 & \\
\cline { 2 - 5 } & 4 & 91.9 & 3156.9 & Banded Gneiss \\
\hline & 6 & 8.67 & 3460.3 & \\
\cline { 2 - 5 } & 5 & 6.77 & 22752 & Granite Gneiss \\
\cline { 2 - 5 } & 7 & 6.72 & 25840 & \\
\cline { 2 - 5 } & 9 & 3.45 & 18241 & Porphyroblastic Gneiss \\
\hline Sedimentary Complex & 8 & 2.28 & 1723.9 & Abeokuta Formation \\
\hline
\end{tabular}



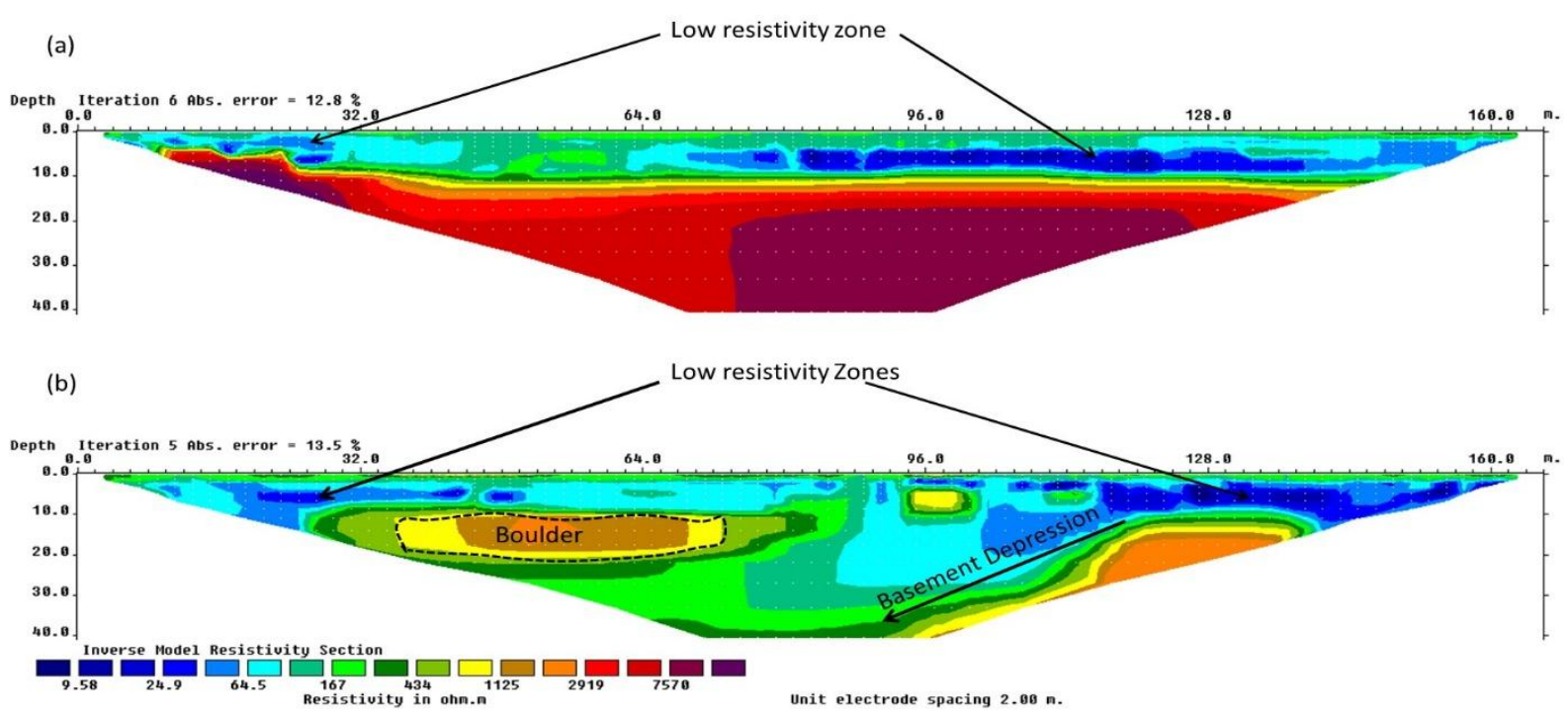

Fig. 2. Inverted Resistivity Section (a) Traverse 1 (b) Traverse 3.

Traverse 4 was taken as control for other traverses, for as at the time of this study, this traverse length showed no visible crack or any form of failure. The lowest resistivity value is $91.90 \mathrm{ohm}$ $\mathrm{m}$ with the inverted resistivity section of this traverse (fig. 3.) showing a relatively higher resistivity value for approximately the top $10 \mathrm{~m}$ (weathered layer). The lithology of this traverse comprises of four layers. The first is the topsoil, followed by high resistivity layer, which we have inferred as probably sandstones. The third layer shows a resistivity of less than 537 ohm-m, this is we have inferred to be the saturated unit, while the basement closely follows at a depth of occurrence of $38 \mathrm{~m}$ and resistivity value of about $1875 \mathrm{ohm}-\mathrm{m}$. The stability of the pavement along this traverse is attributed to the absence of an expansive low resistivity zone and possible deep occurrence of the weathered layer. The resistivity section for the traverse that falls on the sedimentary complex (Traverse 8) is shown in fig. 4a, with an inferred five layer lithology (Table 1). It can be observed on the section that the layering, as expected for sediments is seen, which is absent from previous resistivity sections. From the surface to a depth of about 10m, a resistivity value above 100 ohm- $\mathrm{m}$ is observed, followed by an approximately $20 \mathrm{~m}$ thick low resistivity zone (less than $25 \mathrm{ohm}-\mathrm{m}$ ). This layer can be inimical to the stability of structures, as field observation of the pavement revealed the presence of potholes al ong this section of the road. Below this layer are layers with resistivity values greater than 400 ohm-m an indication of a sandy/sandstone materials (Table 1 ).

As part of the objective of this study is to have a better understanding of the geology of subsurface, the 2-D ERI was capable of imaging the lithological sequence as we transit from the geological formation to the next. Although quite a number of variables are responsible for any resistivity signature observed, this study has shown that the technique is capable of distinguishing between geologies, especially as we observed a progressive decrease in bedrock resistivity as we approached the sedimentary complex boundary. The bedrock structures is clearly imaged by this technique and it can provide a potent way by which the bedrock, as well as geological boundaries can be effectively mapped.

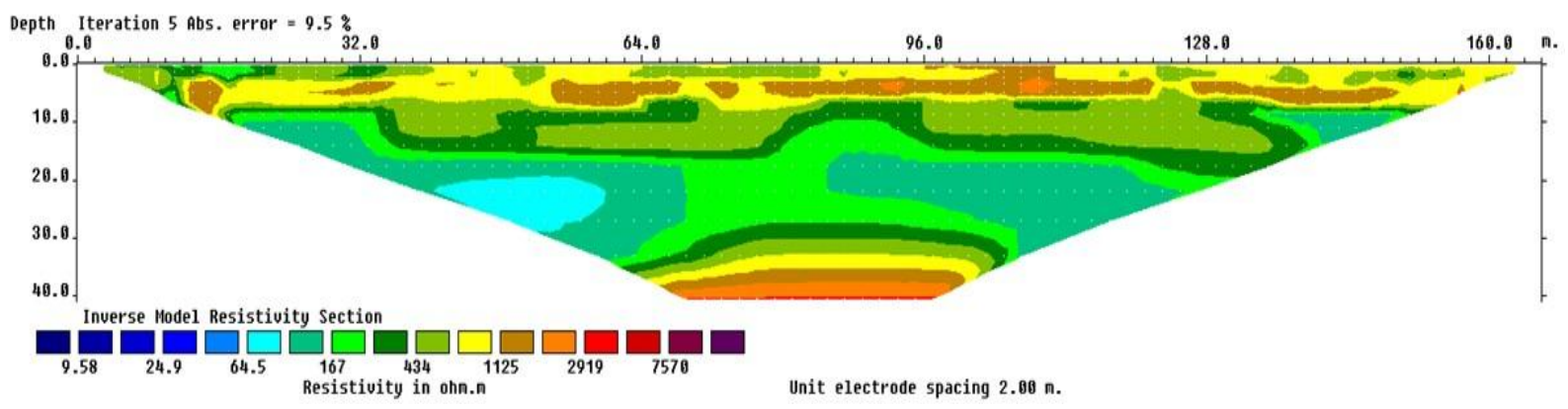

Fig. 3. Inverted Resistivity Section of traverse 4 (Stable segment of the road). 


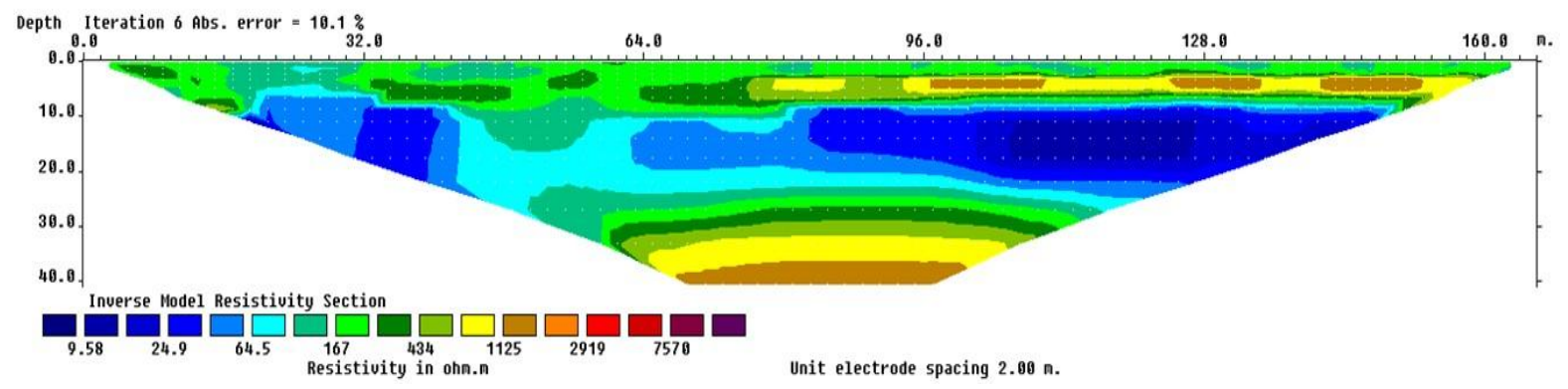

Fig. 4. Electrical Imaging section of traverse 8 (on the sedimentary complex).

\section{Conclusion and Recomendation}

In order to understand the subsurface geology and its effect on the integrity of the Ago-Iwoye to Ishara road of Ogun State, south western Nigeria, a 2-D Electrical Imaging (2-D ERI) study was carried out. The effectiveness of the electrical survey technique is based on its ability to relate the obtained geoelectrical heterogeneity to lithological variations in the subsurface. For our study area, the number of lithogical layer inferred for traverses on the basement complex ranged from 3 to four with inferred lithology of topsoil, clay, clayey sand/sand and fresh basement. That for traverse on the sedimentary complex ranged from three to five layers, ranging from clay, clayey sand, sand, bedrock.

From our study, we have identified two basic lithological sequences that could compromise the integrity of the pavements:

1. The presence of relatively very low resistivity zones as was identified on almost all the traverses, except on traverse four which as at the time of this study had no visible crack/pothole on it. The closeness of this layer to the surface, its thickness and extent can lead to differential settling, which may result in the loss of pavement integrity.

2. Geological features such as basement/bedrock depression as identified on some profiles are inimical to the integrity of the subsurface as they can lead to the accumulation of water, which in turn can lead to pavement failure.

Furthermore, the 2-D ERI was able to effectively characterize the change in lithologic sequence as we traverse from basement complex rocks to the sedimentary complex rocks. This makes the 2D ERI a tool capable of providing a cost-effective and rapid view of the subsurface.

In view of the possible heterogeneous nature of the subsurface, as depicted by this study, along various traverses, it is important that geophysical survey be included as one of the techniques for site investigation, prior to any construction. This is particularly paramount for structures that traverse transition zones such as this study area, as the result if properly designed and implemented can provide a wealth of information that would complement other traditional geotechnical and geologic techniques.

\section{References}

Adepelumi, A., \& Olorunfemi, M. 2000. Engineering geological and geophysical investigation of the reclaimed Lekki Peninsula, Lagos, South West Nigeria. Bulletin of Engineering Geology and the Environment, 582, 125-132.

Adiat, K., Adelusi, A., \& Ayuk, M. 2009. Relevance of Geophysics in Road Failures Investigation in a Typical Basement Complex of Southwestern Nigeria. Pacific Journal of Science and Technology, 51, 528-539.

Ajayi, L. 1987. Thought on road failures in Nigeria. The Nigerian Engineer, 221, 10-17.

Alaia, R., Patella, D., \& Mauriello, P. 2007. Application of geoelectrical 3D probability tomography in a test-site of the archaeological park of Pompei Naples, Italy. Journal of Geophysics and Engineering, 51, 67.

Anderson, N. L., Croxton, N., Hoover, R., \& Sirles, P. 2008. Geophysical methods commonly employed for geotechnical site characterization. Transportation Research E-CircularE-C130.

Ariyo, S., \& Adeyemi, G. 2012. Geo-electrical Characterization of Aquifers in the Basement Complex/Sedimentary transition zone, Southwestern Nigeria. International journal of advanced scientific research and technology, 21 .

Ayolabi, E., \& Adegbola, R. 2014. Application of MASW in road failure investigation. Arabian Journal of Geosciences, 710, 4335-4341.

Emujakporue, O. 2012. Geophysical Investigation Of The Causes Of Highway Failures In Niger Delta Sedimentary Basin A Case Study Of The Eastern Part Of East-West Road, Nigeria. Scientia Africana, 111, 143-152.

Igwe, O. 2015. The causes and mechanisms of raininduced highway and pavement collapse in Obolo-eke, Southeast Nigeria. Arabian Journal of Geosciences, 811, 9845-9855.

K.O, O. 2012. Combination of geological mapping and geophysical surveys for surface-subsurface structures imaging in Mini-Campus and Methodist Ago-Iwoye NE Areas, Southwestern Nigeria. Journal of Geology and M ining Research, 45. doi:10.5897/jgmr12.001 
Kumar, D. 2012. Efficacy of electrical resistivity tomography technique in mapping shallow subsurface anomaly. Journal of the Geological Society of India, 803, 304-307.

Loke, M. 2004. Tutorial: 2-D and 3-D Electrical Imaging Surveys, 2004 Revised Edition.

Metwaly, M., \& AlFouzan, F. 2013. Application of 2$D$ geoelectrical resistivity tomography for subsurface cavity detection in the eastern part of Saudi Arabia. Geoscience Frontiers, 44, 469-476.

Momoh, L., Akintorinwa, O., \& Olorunfemi, M . 2008. Geophysical Investigation of Highway Failure-A Case Study from the Basement Complex Terrain of Southwestern Nigeria.

Oladapo, M. I., Obafemi, M., \& Ojo, S. 2008. Geophysical investigation of road failures in the basement complex areas of southwestern Nigeria. Research Journal of Applied Sciences, 32, 103-112.

Olayinka, A., \& Sogbetun, A. 2002. Laboratory measurement of the electrical resistivity of some Nigerian crystalline basement complex rocks. African Journal of Science and Technology, 31.

Olorunfemi, M., \& Meshida, E. 1987. Engineering geophysics and its application in engineering site investigations Case study from Ile-Ife area. The Nigerian Engineer, 222, 57-66.

Omatsola, M., \& Adegoke, O. 1981. Tectonic evolution and Cretaceous stratigraphy of the Dahomey Basin. Journal of Mining and Geology, 181, 130-137.

Onuoha, D. C. O., S. U. and Obienusi, E. A. 2014. Evaluating the Causes of the Road Failure of Onitsha-Enugu Expressway, Southeastern Nigeria. Civil and Environmental Research ISSN 2224-5790 Paper ISSN 2225-0514 Online Vol.6, No.8, pp. 1118-130.

Rahman, M. 1989. Review of the Basement Geology of Southwest. Nigeria. Geol. Nigeria, 943-959.

Rizzo, E., Chianese, D., \& Lapenna, V. 2005. Integration of magnetometric, gpr and geoelectric measurements applied to the archaeological site of Viggiano Southern Italy, Agri Valley-Basilicata. Near Surface Geophysics, 3, 13-19.

Sobreira, J. F. F., Lipski, M., Carvalho, L. A., \& Márquez, E. 2010. Geotechnical characterization based on seismic data approaches applied in Campos Basin, southeastern Brazilian Margin. The Leading Edge, 297, 842-846.

Wightman, W., Jalinoos, F., Sirles, P., \& Hanna, K. 2004. Application of geophysical methods to highway related problems. Retrieved from www.cflhd.gov/agm/index.htm. 